\author{
Halina Karaś \\ Uniwersytet Warszawski \\ Instytut Języka Polskiego \\ ORCID: 0000-0003-4383-9626; e-mail: h.a.karas@uw.edu.pl
}

\title{
Formy oboczne miejscownika liczby pojedynczej (w) domu - (w) domie w gwarach polskich na Litwie
}

\begin{abstract}
Abstrakt: W niniejszym artykule omówiono oboczne formy miejscownika liczby pojedynczej rzeczownika męskiego dom: $(w)$ domu - (w) domie (a więc zgodną z normą ogólnopolską i analogiczną, powstałą w wyniku wyrównania końcówki fleksyjnej do pozostałych rzeczowników męskich twardotematowych) w gwarach polskich na Litwie, ich zakres i zasięg oraz frekwencję. Podstawą materiałową rozważań jest zbiór 235 form miejscownika lp. rzeczownika dom (domu, domie) i 3 przykłady formy doma wyekscerpowane z nagrań dokonanych w 4 podstawowych enklawach polskojęzycznych, tj. na obszarze ignalińskim, jezioroskim, kowieńskim i wileńskim.
\end{abstract}

Słowa kluczowe: rzeczownik, fleksja, analogia, gwary polskie na Litwie

\begin{abstract}
Alternations of the locative case, singular (w) domu - (w) domie in polish dialects in Lithuania. In this article, the author presents alternative forms of the locative case in the singular of the masculine noun dom: $(w)$ domu - (w) domie (i.e. one which complies with the general Polish standard and a parallel one, a result of levelling an inflection ending to the remaining hard-stem masculine nouns) in Polish dialects in Lithuania, their ranges and frequency. The article is based on a collection of 235 forms of the locative case singular of the noun dom (domu, domie) and 3 examples of the form doma, excerpted from recordings made in 4 major Polish-speaking enclaves i.e. Ignalin, Jeziorosk, Kaunas and Vilnius.
\end{abstract}

Keywords: noun, inflection, analogy, Polish dialects in Lithuania

Celem niniejszego artykułu jest omówienie występowania obocznych form miejscownika liczby pojedynczej rzeczownika męskiego dom: (w) domu - (w) domie w gwarach polskich na Litwie. W wielu publikacjach poświęconych różnym odmianom polszczyzny północnokresowej pojawiają się informacje o wariantach lokatiwu tego rzeczownika. Obok formy zgodnej z normą ogólnopolską z końcówką $-u$ jako nieregularną dla rzeczowników twardotematowych (z wyjątkiem zakończonych na spółgłoski tylnojęzykowe), która jest dziedzictwem dawnych stosunków językowych (psł. deklinacja - $\bar{u}$-), występuje tam forma analogiczna $w$ domie, wyrównana do innych rzeczowników twardotematowych, którym właściwa jest końcówka -e z towarzyszącą jej alternacją tematyczną spółgłoski wygłosowej. Nie jest to jednak osobliwość wyłącznie kresowa, gdyż omawianą formę fleksyjną charakteryzuje szeroki zasięg teryto- 
rialny, znana jest zarówno gwarom Polski etnicznej, polszczyźnie potocznej, jak i językowi polskiemu na dawnych Kresach Wschodnich, zwłaszcza północno-wschodnich. Tożsame wariantywne formy analogiczne mają również dwa inne rzeczowniki twardotematowe: syn (także z dawnej deklinacji -ü-) i pan.

W literaturze przedmiotu poświęconej polszczyźnie kresowej zazwyczaj podaje się tylko wybrane formy osobliwe bez ich frekwencji i stosunku do form zgodnych z normą ogólnopolską. Czasami sygnalizuje się wahania - równoległe występowanie obu form. Warto zatem zbadać, jaki jest zakres omawianych form obocznych i frekwencja w gwarach północnokresowych oraz czy jest widoczne na Kresach ich zróżnicowanie terytorialne.

Podstawą materiałową artykułu jest zbiór 235 form miejscownika 1p. rzeczownika dom, wyekscerpowanych $\mathrm{z}$ nagrań dokonanych $\mathrm{w}$ czterech podstawowych enklawach polskojęzycznych, tj. na obszarze ignalińskim, jezioroskim, kowieńskim i wileńskim. Dotychczas obszar ignaliński i jezioroski był traktowany łącznie jako trzeci tzw. smołwieński obszar językowy (Turska 1939/1995), jednakże ostatnie badania pokazały zróżnicowanie tej enklawy na dwie części: ignalińską, zbliżoną do gwar wileńskich i jezioroską z podobieństwami do gwar kowieńskich (Karaś 2004, 2017). Wszystkie wymienione enklawy polskojęzyczne zostały już stosunkowo dobrze opisane (np. Karaś 2002, 2007, 2015, 2017), dlatego też pomijam charakterystykę sytuacji socjolingwistycznej na badanych obszarach.

Obie formy oboczne zostaną przedstawione $-\mathrm{z}$ uwagi na szeroki zasięg terytorialny formy z końcówką analogiczną - na szerokim tle porównawczym, zarówno innych odmian polszczyzny kresowej - dawnej i współczesnej, jak też gwar Polski etnicznej i polszczyzny potocznej. Uwzględniono również trzecią możliwą formę lokatywną, dziś archaiczną i gwarową doma - obsługującą oczywiście tylko część kontekstów charakterystycznych dla miejscownika - odpowiednik wyrażenia przyimkowego $w$ domu. Warto jednak podreślić, że formy domu - domie występują w analizowanych tekstach gwarowych prawie zawsze z przyimkiem $w$, sporadycznie z przyimkami przy, na. Dla uzyskania pełnego obrazu zbadano też formy miejscownika dom w Narodowym Korpusie Języka Polskiego, by sprawdzić, czy forma analogiczna weszła do polszczyzny ogólnej, a jeśli tak, to w jakim stopniu ten kolokwializm się w niej upowszechnił.

Poniżej przedstawiam materiał językowy zgodnie z terytorialnym zróżnicowaniem gwar polskich na Litwie. Dla wszystkich wyekscerpowanych przykładów form lokatywnych rzeczownika dom (ogólnopolskich i nieogólnopolskich) podaję konteksty i ich lokalizację (skróty oznaczają miejscowość i informatora wraz z rokiem urodzenia).

\section{Obszar ignaliński}

Łącznie w badanym korpusie nagrań z rejonu ignalińskiego ogólna liczba przykładów miejscownika lp. rzeczownika dom regularnego i nieregularnego to 48 form, w tym: $v$ domu $-34, \mathrm{tj} .70,8 \%$; v dom'e 14, tj. 29,2\% (w tym: $v$ dom'e 11, $v$ dom'e ${ }^{a} 3$ ):

- ogp. (w) domu (34):

$v$ domu/ jak na fs"'i Bej.IK[35];

$v$ domu ońi žylí; f tym domu BorHC[35];

trad|ycyja była/ žeby być $v$ domu pšy sob’e Mej.GJ[17]; 
ja ńe byłam $v$ domu i została; žylim p'entnas'c'e l'at $f$ tym domu; v drug'im domu; 'os'im l'uz'i $v$ domu; že ja bez šp'ital'a umža muv'a $v$ domu Pac.HS[25];

čšy dńi čšymajo $v$ domu Rej.WM[22];

p'ens'alńer jest $v$ domu/ to ješče i učšymuji Szmel.PL[19];

nu to $v$ domu pov'es'i tak'e v'erufk'i; k’edys' było $v$ domu tkali Szuł.NK[30];

f tym domu/ to ońi po litefsku Szuł.JS[33];

$v$ domu taka pap'era gruba Tryk.ZS[28];

teras i s'ez'im $v$ domu; skšyńa juš taka była $v$ domu Tryk.WS[32];

žontca žył $f$ tym domu Und.HS[38];

$v$ domu po pol'sku; $v$ domu my muv'ili po polsku; $f$ tym samym domu žyfšy/ i tež był Pol'ak; k'edys' škoła $v$ našym domu była; my fšystk'e $f$ svoim domu xoz'ilí do škoły; $v$ domu po polsku; juš on'i tam $v$ domu pa litefsku rozmav'ajo; $v$ domu teš tak sama; $v$ domu tatus'a juš 3 'ac'ka um'erał; $f$ tym samym domu był; nu to ftedy $f$ tym domu strojo jes'c'; $f$ tym domu/ była zaxorovafšy; ja $v$ domu była/ nu to gaz'ina fkon's'iła Weł.TS[35];

juš mamus'a tak $v$ domu/ ona u svoim; $v$ domu s'ez'eli fr̃ysk'e; $v$ domu tak i po polsku i po rusku Zygm.WT[34];

- nieogp. (w) domie (14):

tyko ježeĺi P'otra/ to $v$ dom'e xto im'eńinńik Bort.HC[35];

tak vo $v$ dom'el u dom'e zb'erali s'a/ nu al'e g3'e tam/ v'ečory Mej.TM[36];

$f$ každym dom'e po jeden po dva l'uz'i Rej.WM[22];

a to u jejnym dom'e Rem.AK[29];

$v$ dom'e ixnym bylí była škoła/ a ońi v drug'im koncu žyĺi Strył.JG[34];

ot $f$ tym dom 'e $e^{a}$ žyli teš; gospodaž dobry žył $f$ tym dom'e; žyli ońi tam $f$ tak'im čterexkvart'irnym dom'e; $v$ dom' $e^{a}$ fšysk'e po poĺsku Szuł.JS[33];

$u$ dom' $e^{a}$ pat padłogaj jest padvalčyk; s'v'encona voda tež drug'i raz bryzgali $u$ dom'e Trycz.LT[32];

kto $v$ dom'e był; a tut $u$ dom'e fs̃yskoš Tryk.WS[32].

\section{Obszar jezioroski}

Z gwar obszaru jezioroskiego ogólna liczba wyekscerpowanych przykładów miejscownika lp. rzeczownika dom z końcówką - $u$ i $-e$ wyniosła 50 form, w tym: (v) domu 23, tj. 46\%; (v) dom'e 27, tj. 54\% (w tym: dom'e 7, dom'e $e^{a} 11$, dom'a 9).

- ogp. (w) domu (23):

v domu |k'edys'c'i s'v'entkovali barzo ład'ńe Jez.JW[36];

puk'i ramont $v$ domu jiz'i Kaln.BS[24];

a $v$ domu/ $v$ domu abej3'is' s'a Mag.MN[20];

po pol'sku $v$ domu/ Mag.BP[31];

mńe ńe čš'eba $v$ domu; ja muja $v$ domu s'eza; čy co ja/ s'eza $v$ domu/ ja ńic ńa $\mid$ v'em; u mńe $v$ domu teš jest; stoji $v$ domu popsuta; taka była $v$ domu zrob’ona tam; i $v$ jednym domu/ i $v$ drug'im domu/ i f tym domu; ńe pšepros'i jeden drug'ego $v$ domu; pšepros'im fšysk'i $v$ domu Now.WK[20];

$v$ jixnym domu Ows.MB[24]; 
$v$ doти my po pol'sku; $v$ domu po pol'sku muv'o Smołw.AS[39];

$v$ jednym domu juž była ustrojona majova Smoł.AŻ[22];

kce s’a na domu na svoja łuška Stal.JG[33];

pa pol'sku gadali $v$ domu Szuk.HD[22];

curka $v$ drug'im domu Szuk.ZJ[23];

- nieogp. (w) domie (27):

(v/na) dom'e 7 razy:

na daxu/ na dom'e tam pov'es'i; to k'edys'c' z'ułkuf tyx na dom'e Duk.AS[46];

$f$ tamtym dom'e ńixt ńe $\mathrm{e}^{\mathrm{a}}$ žyji Mag.MN[20];

to byłam $v$ dom'e i c'el'uk'i yodovałam Muk.JW[25];

po pol'sku i $v$ dom'el i ojcy po pol'sku Nar.MS[20];

čtere 3 "ec"i było $v$ dom'e Smołw.AS[39];

$v$ dom'e råzmav'am'i tak pā poĺsku Stal.AP[35];

$v$ dom'a 9 razy:

jag $v$ dom'a/ to pā polsku/ z 3'adam; $v$ dom'a pa rusku rozmav'a; 'ob'at co raz davalii/ al'a $v$ dom'a davaĺi GirAP[18];

$v$ dom'a rozmav'aĺi my po polsku Jez.JW[36];

u nas tež žarny $f$ tym $o$ dom'a byli zrob'ony Mag.MN[20];

jego ńigdy $v$ dom'a ńa |ma Muk.JW[25];

to tak i $v$ dom'a; teš pa pol'sku $v$ dom'a razmav'ali Nar.MS[20];

jak my ž‘úli $v$ dom'a taka v'irufka/ davńej Smołw.AS[39];

(v/ pšy) dom'e ${ }^{\mathrm{a}}-11$ razy:

tutej juž była $v$ dom' $e^{a}$ mamk'i robota; na dom 'e $e^{a}$ i čšymali jegů DukAS[46];

była kała nas tam $f$ tak'im dom' $e^{a}$ škoła; jego nal'ez'li $v$ dom' $e^{a} \operatorname{Imb}$.WP[39];

tyko mus'i ńe ma jej $v$ dom' $e^{a}$ teras Jez.JW[36];

$f$ tym dom 'e $e^{a}$ žył; o tu jeden brat $f$ tym dom ' $e^{a} ; v$ dom 'e $e^{a}$ to po polsku gadam'i Rom.RV[24];

fšysk'e rozmav'am'i po polsku/ $v$ dom 'e $e^{a}$ Stal.AP[35];

$v$ dom 'e $e^{a}$ pracavalí; tu pšy tym dom' $e^{a}$ aš|če był drug'i tak'i dom muravany Stal.JG[33].

\section{Obszar kowieński}

Łącznie z nagrań dokonanych na Kowieńszczyźnie wyekscerpowano 70 poświadczeń dwóch wariantów miejscownika lp. rzeczownika dom, w tym: (v) domu -41 razy, tj. 58,6\%, (v) dom'e - 29 razy, tj. 41,4\%.

- ogp. (w/ przy) domu (41):

$v$ domu/ tel'efonu odgadneła Aż.WM[27];

"ona mało co $v$ domu ji růb'iła Bart.WP[31];

ja to $v$ domu mało był; $v$ domu čše była byc' Dat.RS[23];

$v$ domu xovalim s'a; tu $v$ domu žona žyła Kiej.FT[13];

pšy tym našym domu Kiej.WK[36]; 
rozmav'alis'my cały čas $v$ domu pô pol'sku Kiej.RG[30];

a $v$ dоти "on pu litefsku; my tak růzmav'áli $v$ domu Korm.AG[15];

$v$ doти z z'ac'instva ja pu p ${ }^{\tilde{n}} \mathrm{O}$ 'sku Korm.WR[49];

$v$ dоти i rozmav'ajon pů pol'sku; fšystko $v$ domu rub'ilí; $f$ tym domu Kow.JS[24];

$v$ doти rob'íli; $v$ dоти rob'íli truny; było komu $v$ doти Piad.J[12];

$v$ domu pů litefsku Piad.MJ[18];

ńe $e^{\mathrm{a}}$ byva $v$ domu; ja $v$ domu ńa byłam; "on půgńevał s'e z |brac'am'i $v$ domu Ong. $\mathrm{AU}[13]$;

ńe pracovała / $v$ domu Pon.WK[36];

a $v$ domu to po litefsku juž Rosz.WR[40];

$v$ doти p'eḱlim xl'ep// v domu p'eklím; p'eklí xl'eb $v$ domu; $v$ domu p'ečym xl'ep Sz.J[17];

dv'e nocy $v$ domu čšymamy; my $v$ domu tu juš zafše ruzmav'alim pô pol'sku Św.IP[27];

fspomńeńe $v$ domu rob'ili Urn.GA[16];

po pol'sku rozmav'aĺi $v$ domu; ńe spalis'my $v$ domu; $v$ domu podros'ĺim; půmagalim $v$ domu Wędz.ZB[21];

navet i $v$ domu rozmav'ajů roz'icè po polsku; tyko $v$ domu vłas'c'ic'ela Wędz. $\mathrm{SW}[26]$;

dv'e c'alícy $v$ domu Wil.JR[32];

tam $v$ doтu m'elim Wil.JB[22];

a $v$ dоти žeby to ńic ńe m'ec' WŁop.TK[32];

my $v$ domu cały čas po polsku růzmav’aliśmy Wod.LT[20];

a my $v$ dоти po polisku Żeg.SW[20].

- formy nieogp. (w) domie (29):

$v$ dom'e -13 razy

byva $\mathrm{f}$ T'eal'š'aj $f$ svojim dom'e / a ja tutaj byvam $f$ svojim dom'e Kiej.WK[ 36]; $n^{\mathrm{a}} v$ moim dom'e Kom.BM[18];

ńe było komu rob'ic' $v$ dom'e; jeden o tu $v$ dom'e; líčyli $v$ dom'e Krok.AB[31] ;

$v$ dom'e z z'ec'am'i po polsku gadali cały čas. Lipl.JT[38];

p'erv'ej $v$ dom'e rob'íli te truny Mitr.HL[16];

spał $v$ dom'e Pon.WK[36];

f kaz'onym dom'e m'eškalim Rosz.WR[40];

my $v$ dom'e v'encej juš po litefsku; $v$ dom'e juš po l'itefsku Wędz.JB[46];

my teraz žyjim $f$ tym dom'e Wil.JB[22];

(v/ pšy) dom'e $e^{a}-16$ razy

na m'ejscu dom pšy dom' $e^{a}$ Bart.WP[31];

$v$ dom' $e^{a}$ gusp ${ }^{u}$ odarka ńea mała m'elim Św.IP[27];

pšy dom' 'e tyků pracovała/ pšy dom' $e^{a}$ Piad.J[12];

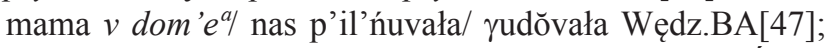

kub'eta žyła za s'c'ano $f$ tym putdom ' $e^{a}$; s'v'entkovali $v$ dom ' $e^{a}$, ńigdy $f$ tym dom 'e $e^{a}$ ńa nocovała Wędz.JP[31]; 
jego matka $v$ dom' $e^{a}$ muv'i po polsku Wod.LT[20 ];

pšy tym dom'e $e^{a} /$ pšy tyx lipax; rob'iłam tam $f$ tym dom'e ${ }^{a}$ Ong.AU[13];

tyka $v$ dom' $e^{a} / \mathrm{v}$ bunk'eru Św.OP[23];

$f$ svoim juš dom 'e $e^{a}$ 'v'vantkovalí; $v$ jednym tam dom 'e $e^{a}$ žylim; ubdarovac' $f$ svojim dom 'e $e^{a}$ Wędz.JP[31].

\section{Obszar wileński}

Z nagrań dokonanych na obszarze wileńskim wyekscerpowano 67 form miejscownika lp. rzeczownika dom, w tym form zgodnych z normą ogólnopolską $(w)$ domu 55 , tj. 82,1 \%, form analogicznych $(w)$ domie - 12, tj. 17,9\%.

- ogp. (w/na) domu - 55 razy:

$v$ domu spšontac' Andr.LR[36];

3'ev'eńc'u $v$ domu žyli; teraz o jedna $v$ domu; a k'edys' až z'ev'eńc'u $v$ domu; dvaz'estu $v$ jednym domu byli Czer.HM[35];

Sov'ety złapaĺi jego $v$ domu; $v$ domu, to ja ńe v'em, jak "ońi m’enzy sobo; $v$ domu s'ez'iš Ejsz.OS[27];

późńej v domu Ejsz.JK[13];

mus'ała zostać $v$ domu Ejsz.IG[28];

jag $v$ domu była taka m’eli; ja była $v$ domu Gier.K[30];

rob'ili my sam'i $v$ domu; xojinečka m'eĺi $v$ domu Gow.JN[20];

$v$ domu, z'ež ońi pońoso Hąs.JK[34];

tak'i z žyta splec'i s'e, $v$ domu, v'anak to v'is'i $v$ domu; z'efčynk'i młode $v$ domu; gospodažem ben'z'e $v$ domu; $v$ domu ńe stav'ali; potančyć p'erfs̃y ras $f$ tym domu Kab.MG[29];

s'ezu $v$ domu; otkryĺi tu $v$ domu; $v$ domu ńi byvamy; te rublí $v$ domu zmarnovali s'e Kam.ZK[33];

ńe pam'entam žeby u nas $v$ domu ro ${ }^{\mathrm{u} z m a v}$ 'aĺi tym prostym jenzyk'em; ja ńe mam s k'im $v$ domu ro 'zmav'ac'; $v$ domu zam'atajo; bałagan jak'i $v$ domu Kol.K[27]; v našym domu, a f tym domu; v domu juš ja byłam vyučona čytac' i p’isac' Kork. $\mathrm{JK}[11]$;

tam v domu Trabuc' "ova taka stara juš Kork.WG[29];

ńe v domu, p ošečšy do kos'c' "uła Kork.LM[38];

$\mathrm{v}$ domu była, a p potym pšy ko ${ }^{\mathrm{u}}$ s'c'el'e całyn čas Kork.SS[08];

$v$ domu tako źb'erajon s'e Podb.AP[15];

3'ec'i byĺi $v$ domu Magn.HS[44];

potem $v$ domu, $v$ domu v'encej tak o; jak stalše to $v$ domu v'encej; na peńs'iji to $v$ domu Magn.ZM[29];

$v$ domu po polsku Magn.PJ[12];

$v$ domu povoz'iłosep; na ostatńim domu; $f$ tym domu; prav'e $f$ kuždym domu; $v$ domu pajonk Poj.TK[42];

čšeba było v domu; xorego m’ałam v domu; ja v domu modlim s’a; v d"omu po b'ałarusku; jedna v d omu Pren.HS[22]; 
- formy nieogp. (w/ przy) domie - 12 razy:

z'ec'i małe $v$ jednym duom'e Andr.PG[25];

l'uz'i žyjo ješče $f$ tym dom'e žyjo Andr.LO[30]

teras $f$ p'ontym dom'e Ejsz.TW[29];

ńektužy $v$ dom'e užonz'ifšy tak'e ołtažy Magn.HS[44];

tag v'iz’i jak juž dom pšy dom'e Magn.WG[30];

najezdne of tym dom'e Niem.CN[31];

$v$ drug'im dom'e juš pšyjeńc'e Poj.TK[42];

f tym dom'e kulitury była; f tym dom'e tam m'eškała; v jixnym d"om'e Pren. HS[22];

f tym dom'e, f kturym značy kontora WSał.MK[14].

Obok przedstawionych wyżej dwóch wariantów lokatiwu dom (domu - domie) występującego głównie z przyimkiem $w$ (224 razy - 95,3\%), rzadko z przyimkami $n a$ (4 razy $-1,7 \%)$, przy (7 razy $-3 \%$ ), sporadycznie odnotowano $\mathrm{w}$ badanym materiale miejscownik doma, odpowiednik wyrażenia przyimkowego $w$ domu, po jednym przykładzie z obszaru jezioroskiego, ignalińskiego i kowieńskiego, nie poświadczono go w tekstach z Wileńszczyzny:

m'ał p'in'ondzy/ to on u bal'n'icy/ a ja doma Min.JJ[35];

nu to mału na robota xoz'iła/ pšy saụxoz'e damaxaz'ajka može byc' doma/ to mało xoz'iła Rej.WM[22];

no to on tag doma ix učył / jak on tam mok Wojn.PC[24].

Nie zarejestrowano w badanych nagraniach z obszaru Litwy formy $w$ doma, występującej na Kresach południowych (podtrzymywanej tam interferencją języka ukraińskiego) i w gwarach Polski etnicznej (por. SGPK, SGPPAN, SGOK, ILGiKP).

Dane liczbowe i procentowe dotyczące występowania form lokatywnych rzeczownika dom: (w) domu - (w) domie - doma w gwarach polskich na Litwie z uwzględnieniem ich zróżnicowania terytorialnego przedstawia tabela 1 .

Jak widać, warianty z końcówką ogólnopolską - $u$, wyjątkową na tle pozostałych rzeczowników męskich twardotematowych (oprócz zakończonych na spółgłoski tylnojęzykowe) i z końcówką -e analogiczną do twardotematowych masculinów występują w gwarach wszystkich enklaw polskojęzycznych. Ich udział jest jednak różny w badanych odmianach terytorialnych polszczyzny północnokresowej.

Łącznie obie formy: $(w)$ domu i $(w)$ domie wystąpily 235 razy w badanym materiale, w tym forma tożsama z ogólnopolską (w) domu ma 153 poświadczenia, czyli ich odsetek wynosi $64,3 \%$, natomiast forma ( $w$ ) domie z końcówką -e wyrównaną do pozostałych masculinów twardotematowych (wraz z jej wariantami fonetycznymi) została odnotowana rzadziej (prawie dwukrotnie) - 82 razy, tj. ich udział w całym zbiorze wynosi $34,5 \%$. Oznacza to, że prawie co trzeci przykład poświadcza proces wyrównania końcówki fleksyjnej. Archaizm doma pojawił się sporadycznie - 3 przykłady, tj. $1,3 \%$ całości zebranego materiału. 
Stosunek wariantów miejscownika $(w)$ domu - (w) domie jest zróżnicowany w uwzględnionych enklawach polskojęzycznych. Ich udział procentowy (bez formy doma) w gwarach używanych przez społeczność polską tych enklaw ilustruje wykres 1 .

Tabela 1. Liczebność i odsetek form ogólnopolskich i nieogólnopolskich Msc.lp. rzeczownika dom w nagraniach gwar z czterech enklaw polskojęzycznych.

\begin{tabular}{|l|l|l|l|l|l|l|l|}
\hline \multirow{2}{*}{$\begin{array}{l}\text { Obszar } \\
\text { gwarowy }\end{array}$} & \multicolumn{2}{|l|}{ Ogp. (w) domu } & \multicolumn{2}{l|}{ Nieogp. (w) domie } & \multicolumn{2}{l}{ Nieogp. doma } & \multirow{2}{*}{ Razem } \\
\cline { 2 - 8 } & Liczba & Procent & Liczba & Procent & Liczba & Procent & \\
\hline Ignaliński & 34 & $69,4 \%$ & 14 & $28,6 \%$ & 1 & $2 \%$ & 49 \\
\hline Jezioroski & 23 & $45,1 \%$ & 27 & $52,9 \%$ & 1 & $2 \%$ & 51 \\
\hline Kowieński & 41 & $57,7 \%$ & 29 & $40,8 \%$ & 1 & $1,4 \%$ & 71 \\
\hline Wileński & 55 & $82,1 \%$ & 12 & $17,9 \%$ & - & - & 67 \\
\hline Razem & 153 & $64,3 \%$ & 82 & $34,5 \%$ & 3 & $1,3 \%$ & 238 \\
\hline
\end{tabular}

Źródło: opracowanie własne.

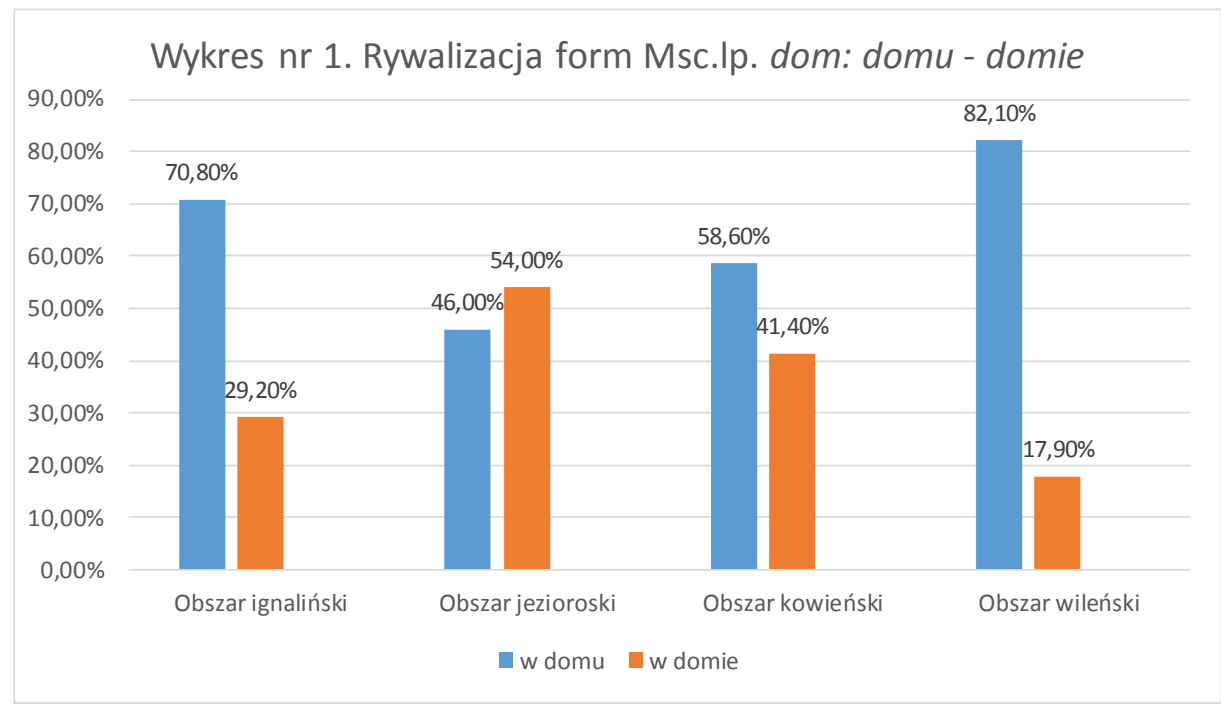


W gwarach trzech obszarów polskojęzycznych: ignalińskim, kowieńskim i wileńskim dominuje forma lokatywna zgodna z normą ogólnopolską (odpowiednio 82,1\% przykładów na Wileńszczyźnie, 70,8\% - na obszarze ignalińskim, 58,6\% - na obszarze kowieńskim), użycia formy analogicznej z końcówką -e są rzadsze. Jedynie w polszczyźnie jezioroskiej większość stanowią poświadczenia formy analogicznej (54\% użyć). Najmniej przykładów z końcówką -e typu $w$ domie odnotowano na Wileńszczyźnie - jedynie 12, czyli 17,9\% form Msc.lp. analizowanego rzeczownika. Można się tu dopatrywać wpływu szkoły polskiej na obszarze wileńskim i ignalińskim na frekwencję tych form $\mathrm{w}$ języku informatorów, tzn. przewagę form z końcówką - $u$, tożsamych $\mathrm{z}$ ogólnopolskimi.

Widać tu też, że gwary obszaru wileńskiego i ignalińskiego pod względem odsetka form analogicznych i ogólnopolskich są zbliżone do siebie, natomiast gwary jezioroskie zbliżają się bardziej do kowieńskich, choć oczywiście stosunki procentowe form ogólnopolskich i analogicznych (nieogólnopolskich) między tymi odmianami nie są aż tak sobie bliskie, w jednym wariancie przeważają, choć nieznacznie, formy nieogólnopolskie, w drugim - ogólnopolskie.

Zauważyć można zróżnicowanie idiolektalne pod względem użycia omawianych wariantów. Nierzadko w tym samym idiolekcie mamy do czynienia z formami obocznymi, por. np. $v$ dom'e / v domu Bort.HC[35]; Tryk.WS[32]; $v$ domu / v dom'a Jez. JW[36]; Mag.MN[20]. Zróżnicowanie idiolektalne tych form przedstawia tabela 2.

Część respondentów używa wyłącznie formy lokatywnej zgodnej z normą ogólnopolską. Czasem ze względu na mała liczbę poświadczeń trudno orzec, jaka forma jest im właściwa. Wyróżniają się tu zwłaszcza dwa idiolekty: informatorki z Wełun z obszaru ignalińskiego z 13 poświadczeniami jedynie postaci domu oraz z Nowików $\mathrm{z}$ obszaru jezioroskiego z 11 poświadczeniami także formy $w$ domu. Obie respondentki mają duży kontakt z polszczyzną ogólną, udzielają się w kościele, mają kontakty z Polakami z Polski. Obie też uczyły się w polskich szkołach. W języku innych osób zarejestrowano wyłącznie formę analogiczną z końcówką -e, np. z Wędziagoły na Kowieńszczyźnie (6 poświadczeń) czy z Dukiszek, Girsi i Imbrodów z obszaru jezioroskiego. Są to informatorzy, którzy nie mieli możliwości kształcenia się w polskich szkołach, nie mają też większego kontaktu z polszczyzną ogólną. Wydaje się zatem, że nauka w polskich szkołach, kontakt z polszczyzną jako językiem religijnym w kościele, z polszczyzną ogólną, m.in. poprzez rodziny w Polsce, sprzyja stabilizacji form zgodnych z normą ogólnopolską. 


\begin{tabular}{|c|c|c|c|c|c|c|c|c|c|c|c|c|c|c|c|}
\hline \multirow{3}{*}{ 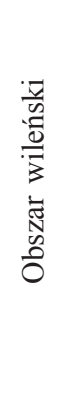 } & : & I & - & - & ' & ' & ' & ' & - & ' & & & ' & & ' \\
\hline & ¿ & - & ' & 1 & $\nabla$ & - & - & $m$ & ' & $\sim$ & $\sim$ & - & 0 & $\nabla$ & $\nabla$ \\
\hline & 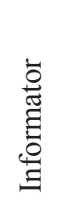 & 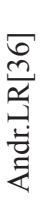 & 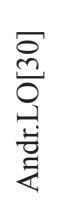 & 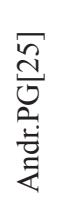 & 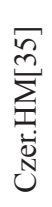 & 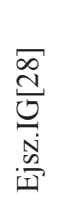 & 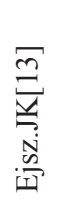 & 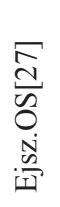 & 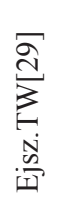 & 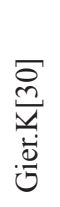 & 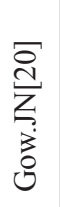 & 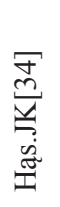 & $\begin{array}{l}\bar{\Xi} \\
\sum_{0} \\
0 \\
\tilde{\Xi}\end{array}$ & 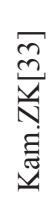 & $\begin{array}{l}\underset{\mathbb{U}}{\underline{\Delta}} \\
\overline{\vec{a}} \\
\end{array}$ \\
\hline \multirow{3}{*}{ 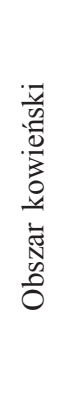 } & : & , & - & 1 & , & & $N$ & - & ' & , & & - & $N$ & $N$ & ' \\
\hline & : & - & - & $N$ & $N$ & - & - & ' & $N$ & - & $m$ & ' & $m$ & n & - \\
\hline & 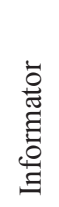 & 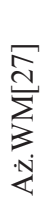 & 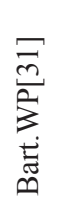 & 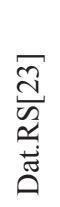 & 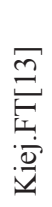 & 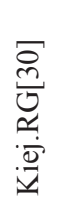 & 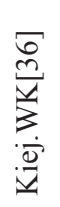 & 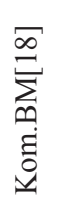 & 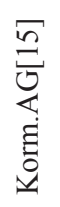 & 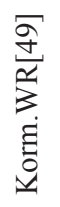 & 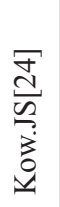 & 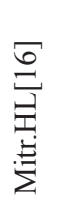 & 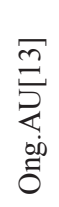 & 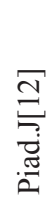 & 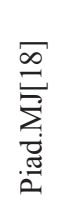 \\
\hline \multirow{3}{*}{ 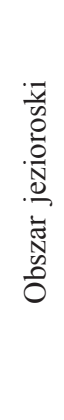 } & : & $\nabla$ & $m$ & $\sim$ & $m$ & 1 & ' & $\sim$ & $\sim$ & $m$ & & & $m$ & & $N$ \\
\hline & ¿ & ' & 1 & 1 & - & - & - & $N$ & , & 1 & $=$ & - & ' & - & N \\
\hline & 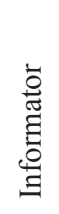 & 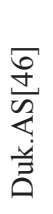 & $\underset{\stackrel{\infty}{0}}{\stackrel{\infty}{\overrightarrow{0}}}$ & 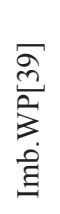 & 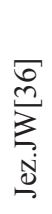 & 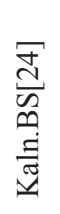 & 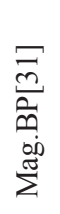 & 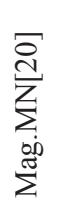 & 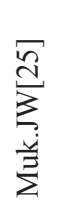 & 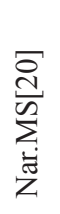 & 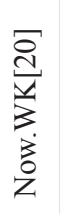 & 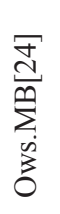 & 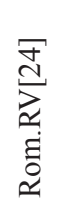 & 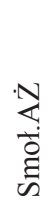 & 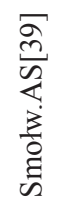 \\
\hline \multirow{3}{*}{ 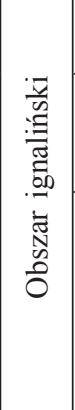 } & : & 1 & - & ' & $\sim$ & & - & - & - & ' & $\nabla$ & & $N$ & & $N$ \\
\hline & בิ & - & - & - & ' & $n$ & - & ' & 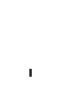 & - & - & $\sim$ & ' & - & $N$ \\
\hline & 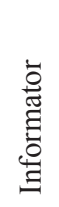 & $\begin{array}{l}\tilde{n} \\
\stackrel{\tilde{y}}{y}\end{array}$ & 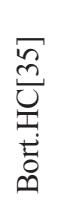 & $\begin{array}{l}\underset{\Xi}{\Xi} \\
\stackrel{\overrightarrow{0}}{\Sigma}\end{array}$ & 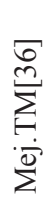 & 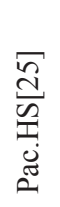 & 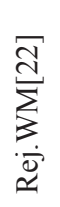 & 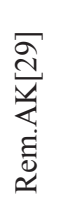 & 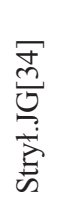 & 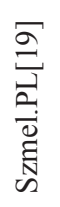 & 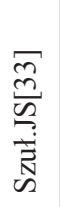 & 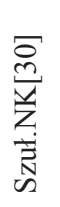 & 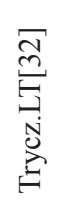 & 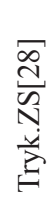 & 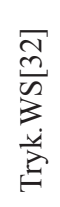 \\
\hline
\end{tabular}


Formy oboczne miejscownika liczby pojedynczej $(w)$ domu $-(w)$ domie ...

\begin{tabular}{|c|c|c|c|c|c|c|c|c|c|c|c|c|c|c|}
\hline ' & ' & ' & ' & - & 1 & - & ' & - & ' & - & $m$ & - & & \\
\hline$m$ & - & - & - & - & - & 1 & $\nabla$ & 1 & - & in & $n$ & I & & \\
\hline 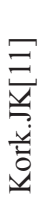 & 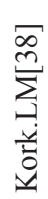 & 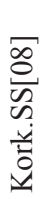 & 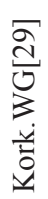 & 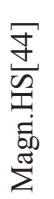 & 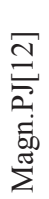 & 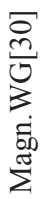 & 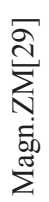 & $\begin{array}{l}\bar{\Xi} \\
\stackrel{ٍ}{Z} \\
\dot{\Xi} \\
\stackrel{0}{z}\end{array}$ & 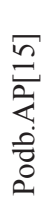 & $\begin{array}{l}\stackrel{ }{J} \\
\stackrel{v}{V} \\
\dot{0}\end{array}$ & 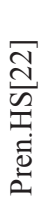 & 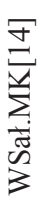 & & \\
\hline- & - & 1 & - & - & 1 & - & $N$ & 0 & 1 & 1 & - & I & - & , \\
\hline- & - & $\nabla$ & $N$ & 1 & - & ' & ' & 1 & $N$ & $\nabla$ & $N$ & - & - & - \\
\hline 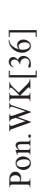 & 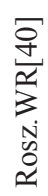 & $\begin{array}{l}\text { E } \\
\stackrel{\vec{M}}{N} \\
\stackrel{N}{\sim}\end{array}$ & 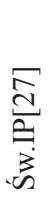 & 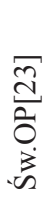 & 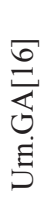 & 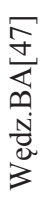 & 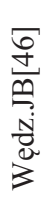 & 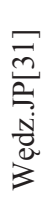 & $\begin{array}{l}\text { D } \\
\text { d } \\
3 \\
\text { in } \\
\text { d } \\
\text { i } \\
3\end{array}$ & 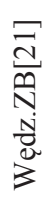 & 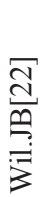 & 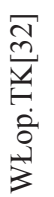 & 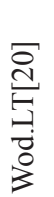 & 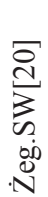 \\
\hline$N$ & $N$ & 1 & , & & & & & & & & & & & \\
\hline 1 & - & - & - & & & & & & & & & & & \\
\hline 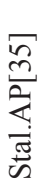 & 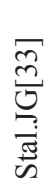 & 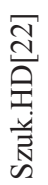 & 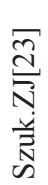 & & & & & & & & & & & \\
\hline 1 & ' & 1 & & & & & & & & & & & & \\
\hline- & $\cong$ & $n$ & & & & & & & & & & & & \\
\hline 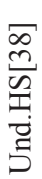 & 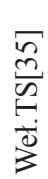 & 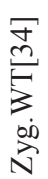 & & & & & & & & & & & & \\
\hline
\end{tabular}

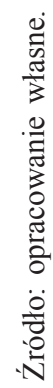


Jak już wspomniano, wahania końcówek -u //-e w miejscowniku lp. omawianego rzeczownika mają szeroki zasięg i długi (kilkuwiekowy) okres występowania. Forma (w) domie z końcówką -e wyrównaną do innych męskich rzeczowników twardotematowych pojawiła się jako skutek analogii w polszczyźnie literackiej okresu średniopolskiego. Stownik polszczyzny XVI wieku (t. V, s. 302) potwierdza ją m.in. jako wariant bardzo rzadki z języka Jana Kochanowskiego, Mikołaja Reja, Marcina Bielskiego, Stanisława Orzechowskiego, Szymona Budnego, Jakuba Wujka, Piotra Skargi. Frekwencja obu wariantów w SPXVI jest wyrazista: 1288 przykładów lokatiwu domu i jedynie 29 - domie, prawie zawsze jako forma oboczna (por. odnotowane wahania w Zwierciadle Reja 23 : 1, Żywotach Skargi 45 : 3, w NT Wujka 51 : 2, w Pieśniach Kochanowskiego 5 : 1). Jako odrębne hasło SPXVI notuje doma 'w domu, w mieszkaniu, u siebie; we własnym gospodarstwie, przy rodzinie’ - 523 przykłady. Linde poświadcza w haśle dom liczne jeszcze użycia doma, w cytatach pojawia się forma $w$ domu, obocznej $w$ domie brak (L, I, 479-481). Odrębne hasła dom i doma (przysł.) ma SWil (I, 233-234), który nie poświadcza wariantu $w$ domie, podobnie w SW (I, 501-502, doma - starop. i gwar.). W SJPD doma daw., dziś gwar. w haśle dom (SJPD, II, 256), cytaty z Dąbrowskiej, Gojawiczyńskiej, Grozy, Syrokomli. Forma miejscownika lp. $w$ domie nie została $\mathrm{w}$ nim zarejestrowana.

Oboczne formy miejscownika liczby pojedynczej rzeczowników męskich dom, syn, pan mają już długą tradycję w polszczyźnie północnokresowej, także od XVI wieku do dziś. Rejestrowano je w różnych jej odmianach, zarówno w wariancie kulturalnym, jak i w języku warstw niższych. W języku akt Wielkiego Księstwa Litewskiego XVIXVIII wieku odnotowano 13 przykładów $w$ domie (Kurzowa 1993, 167), kilka w języku wspomnień Antoniego Sapiehy z XVII wieku (Smolińska 1983, 67). Licznie zostały poświadczone w języku pisarzy końca XVIII i XIX wieku; m.in. u Juliana Ursyna Niemcewicza (Waszkis 1973, 184), Aleksandra Fredry (Bajerowa 1992, 52), Władysława Syrokomli (Trypućko 1955, 259), filomatów, Ignacego i Jana Chodźków (Kurzowa 1983, 259), Juliusza Słowackiego (Klemensiewicz 1961, 290). Wahania w użyciu wariantów $w$ domu (2 przykłady) - $w$ domie (4 przykłady) zarejestrowano również w języku Pana Tadeusza Adama Mickiewicza (Szpiczakowska 2001, 112) i w języku wspomnień jego brata Franciszka (Trypućko 1970, 64). Nieustabilizowanie normy w tym zakresie i wahania $-e /-u$ zostały potwierdzone w tekstach I połowy XIX wieku (Gajda 1973, 98).

Warto podkreślić, że wariant $w$ domie był aprobowany przez niektórych gramatyków końca XVIII i XIX wieku, m.in. przez Onufrego Kopczyńskiego, Maksymiliana Jakubowicza, Tomasza Kurhanowicza, Antoniego Małeckiego (Bajerowa 1992, 52). Niektórzy autorzy gramatyk dopuszczali zatem równoległość obu końcówek w tym rzeczowniku z wyjątkową końcówką - $u$ (M. Jakubowicz, T. Kurhanowicz), inni próbowali uzależnić ich repartycję od kryterium znaczeniowego (A. Małecki). Niemniej jednak akceptowalność wariantu $w$ domie przez przynajmniej część gramatyków - jak się wydaje - spowodowała, iż ustabilizował się on nie tylko w polszczyźnie potocznej, w gwarach, ale także w wariancie kulturalnym, zwłaszcza polszczyzny regionalnej, kresowej. W późniejszych gramatykach już ta postawa wobec wyjątków jest jednoznaczna, nie dopuszcza się wariantu z końcówką analogiczną -e. Podobnie w innych dwudziestowiecznych wydawnictwach normatywnych, poradnikach, słownikach, prze- 
strzega się przed postacią lokatiwu $w$ domie, (por. np. Szwed 1931, 30 [w domu, nie: w domie]), SPPSzob, SPPD, NSPP.

Wahania co do wyboru końcówki miejscownika lp. wyrazu dom, a także syn, pan, wyraziste są we współczesnej polszczyźnie w różnych jej odmianach na dawnych Kresach, częściej północnych niż południowych. Sygnalizują je badacze gwar Wileńszczyzny (Dwilewicz 1997, 46; Grek-Pabisowa, Maryniakowa 1997, 67), Kowieńszczyzny (Karaś 2002, 192), gwar na Białorusi, np. w Widzach (Czyżewski 1995, 80), języka prasy polskiej na Litwie (Mędelska 1993, 98; 2001, 141-143), polszczyzny standardowej studentów polonistyki wileńskiej (Karaś 1996, 66) i uczniów szkół polskich na Litwie (Karaś 1999, 50) oraz języka przesiedleńców z Nowogródczyzny (Lewaszkiewicz 2017, 237-238). Wiele poświadczeń i obszerne omówienie repartycji końcówek -e/l-u w rzeczownikach dom, syn, pan znalazło się w monografiach Jolanty Mędelskiej (2000, 74): domie (24 przykłady), synie (8 przykładów) oraz (Mędelska 2001, 141143): $w$ domie jako odpowiednik ogp. $w$ domu (7 przykładów) i o synie jako odpowiednik ogp. o synu (27 przykładów).

Na dawnych Kresach południowych wariant $w$ domie jest rzadszy, gdyż obok form $w$ domu - $w$ domie (np. Rudnicki 2000, 74) używane są postaci lokatiwu doma i $w$ doma (Cechosz 2001, 77; Dzięgiel 2001, 67), podtrzymywane oddziaływaniem języka ukraińskiego ( $w$ doma) i rosyjskiego (doma).

Wyżej wspomniano, że miejscownik $(w)$ domie jest też właściwy gwarom Polski etnicznej. Bogatą dokumentację ma w Słowniku gwar polskich Jana Karłowicza (t. I: hasło dom) i w Słowniku gwar polskich opracowywanym w Polskiej Akademii Nauk (t. VI, z. 1 [16]: hasło dom liczy tu 7 stron). Drugą formą lokatiwu także obszernie zilustrowaną przykładami jest $w$ doma. Jeszcze bogatszą egzemplifikację w obu słownikach ogólnogwarowych ma archaizm doma, zachowany w wielu gwarach polskich. W gwarach Polski etnicznej współwystępują zatem 4 różne formy lokatywne: $w$ domu $-w$ domie $-w$ doma - doma. Współcześnie szerzy się postać zgodna z ogólnopolską, choć danych liczbowych brak (wariant ogp. nie został odnotowany w SGPK i SGPPAN ze względu na dyferencyjny charakter obu słowników) pozostałe formy mają charakter recesywny.

Miejscownik $w$ domie nierzadki jest również w polszczyźnie potocznej, o czym przekonują zarówno ostrzeżenia w wydawnictwach normatywnych, jak i pytania w Internecie o poprawność obu postaci lokatiwu. Nie ma jednak badań, które by pokazały ich stosunek ilościowy. W związku $\mathrm{z}$ tym sprawdziłam funkcjonowanie obu form $w$ domu $-w$ domie w Narodowym Korpusie Języka Polskiego. Celem było uzyskanie odpowiedzi na pytanie, czy forma analogiczna przenika do polszczyzny ogólnej i w jakim ewentualnie stopniu się w niej szerzy.

W NKJP poświadczono 42444 przykłady lokatiwu $w$ domu i jedynie 11 przykładów ilustrujących wariant $w$ domie. Wśród tych 11 przykładów dwa pochodzą $\mathrm{z}$ tekstów gwarowych z Małopolski górskiej, dwa z utworów Andrzeja Sapkowskiego, umiarkowanie archaizowanych, cztery z tekstów pisarzy związanych z dawnymi Kresami, jedynie dwa - z „Dziennika Słupskiego” i z „Magazynu Puls Studenta” - nie mają takich uwarunkowań. Stosunki ilościowe są zatem jasne. Forma analogiczna $w$ domie nie przenika do polszczyzny ogólnej. 
Formy typu $w$ domie, o synie oceniano w literaturze przedmiotu dotyczącej języka Kresów północnych jako przejaw tendencji ogólnopolskiej (Kurzowa 1993, 259) bądź jako archaizmy (Trypućko 1958, 329). Zdaniem Jolanty Mędelskiej (1993, 98) można je traktować jako archaizmy peryferyczne, które przetrwały w wyniku oddziaływania języków wschodniosłowiańskich w okresie powojennym głównie rosyjskiego, w którym tym rzeczownikom właściwa jest końcówka -e.

Niewątpliwie forma $(w)$ domie stanowi przejaw tendencji do usuwania wyjątków, a więc do uproszczenia systemu, miała ona w przeszłości zasięg ogólnopolski, występowała też w języku literackim, choć rzadko. Następnie tendencja ta została zahamowana, forma z końcówką wyrównaną do innych rzeczowników twardotematowych -e nie uzyskała aprobaty normatywnej, wycofała się z polszczyzny ogólnej, pozostając jako przejaw ekspansji tej formy na pewnym etapie rozwoju, a więc jako pewnego typu archaizm w polskich gwarach rdzennych i na peryferiach dawnej Rzeczypospolitej na dawnych Kresach w polszczyźnie kresowej w jej różnych odmianach. Stanowi zatem pewnego typu świadectwo wcześniejszych etapów rozwoju języka, gdy konkurowały ze sobą dwie formy: starsza, odziedziczona z prasłowiańszczyzny i nowsza, analogiczna, która jednak nie zwyciężyła w języku ogólnym, pozostała jednak w różnych nieogólnych odmianach języka polskiego. W gruncie rzeczy wszystkie wyżej podane objaśnienia zawierają $\mathrm{w}$ sobie prawdę: jest to przejaw tendencji ogólnopolskiej, ale zahamowanej w języku ogólnym, innowacja, która zachowała się na peryferiach obszaru polszczyzny także w odmianie kulturalnej, podczas gdy w centrum (na terytorium współczesnej Polski) pozostała tylko w gwarach. Stąd zasadne może być określanie tej innowacji okresu średniopolskiego, która dłużej utrzymywała się na Kresach w dialekcie kresowym, mianem archaizmu peryferycznego, podczas gdy w polszczyźnie ogólnej stała się już tylko innowacją błędną.

$\mathrm{Na}$ zaprezontowanym tle widać, iż forma analogiczna $(w)$ domie, ekspansywna w polszczyźnie wieków wcześniejszych, także w wariancie kulturalnym, występująca również w gwarach Polski etnicznej, choć nieupowszechniona aż tak szeroko ze względu na równoległe częstsze formy $w$ doma - doma, stanowi w gwarach północnokresowych swego rodzaju dziedzictwo wieków wcześniejszych. Sporadyczne przykłady lokatiwu doma w gwarach polskich na Litwie, w zasadzie ich brak na tle stanu gwar Polski etnicznej, wynikają prawdopodobnie z faktu, iż ten archaizm na Litwie kojarzył się przede wszystkim z językiem rosyjskim i był odbierany jako rusycyzm. W związku z tym mógł być unikany. W nielicznych wypadkach jego użycia można się zresztą dopatrywać wpływu wschodniosłowiańskiego, gdyż wystąpił w idiolektach mocno nasyconych rusycyzmami.

\section{Literatura}

Bajerowa I. (1992), Polski język ogólny XIX wieku. Stan i ewolucja, t. II: Fleksja, Katowice. Cechosz I. (2001), Polska gwara Oleszkowiec na Podolu. Fleksja imienna i werbalna, Kraków. Czyżewski F. (1995), Uwagi o gwarze osady Widze koło Brasławia na Białorusi, [w:] Studia nad Polszczyzna Kresowa, t. VIII, red. J. Rieger, Warszawa, s. 70-87. 
Dwilewicz B. (1997), Język mieszkańców wsi Bujwidze na Wileńszczyźnie, Warszawa.

Dzięgiel E. (2001), Polska gwara wsi Zielonej na Podolu na tle innych gwar poludniowokresowych. Fleksja imienna $i$ werbalna, Kraków.

Gajda S. (1973), Oboczności końcówkowe rzeczowników polskich w I połowie XIX wieku, „Rozprawy Komisji Językowej Wrocławskiego Towarzystwa Naukowego”, t. 9, s. 93-114.

Grek-Pabisowa I., Maryniakowa I. (1997), Język polski na Kresach pótnocno-wschodnich dawniej $i$ dziś, [w:] Historia $i$ wspótczesność języka polskiego na Kresach Wschodnich, red. I. Grek-Pabisowa, Warszawa, s. 27-109.

Karaś H. (1996), Uwagi o błędach fleksyjnych w języku studentów polonistyki wileńskiej, „Poradnik Językowy", z. 9, s. 63-70.

Karaś H. (1999), Uwagi o języku uczniów polskich szkót średnich na Litwie, [w:] Język polski dawnych kresów wschodnich, t. II, red. J. Rieger, Warszawa, s. 47-55.

Karaś H. (2002), Gwary polskie polskie na Kowieńszczyźnie, Warszawa-Puńsk.

Karaś H. (2007), Sytuacja języka polskiego na Litwie dziś, [w:] Język polski jako narzędzie komunikacji we współczesnym świecie, red. J. Mazur, M. Rzeszutko-Iwan, Lublin, s. 207-224.

Karaś H. (2015), Odrodzenie polszczyzny czy jej zanik? O sytuacji języka polskiego na dawnych Kresach Wschodnich, „Poradnik Językowy” 2015, z. 8, s. 18-35.

Karaś H. (2017), Język polski pogranicza litewsko-łotewsko-białoruskiego w świetle frekwencji cech językowych, Warszawa.

Karłowicz J. (1882/1984), Podręcznik czystej polszczyzny dla litwinów i petersburszczan, [w:] Studia nad polszczyzna kresowa, t, III, red. J. Rieger, W. Werenicz, Wrocław, s. 33-81.

Karłowicz J. (1900-1911), Stownik gwar polskich, t. I-VI, Kraków.

Klemensiewicz Z. (1961), Szkic gramatycznej charakterystyki języka Słowackiego, [w:] Z. Klemensiewicz, W kręgu języka literackiego i artystycznego, Warszawa, s. 301-366.

Kurzowa Z. (1972), Studia nad językiem filomatów i filaretów. Fonetyka, fleksja, składnia, Kraków.

Kurzowa Z. (1993), Język polski Wileńszczyzny i kresów pótnocno-wschodnich XVI-XX w., Warszawa-Kraków.

L, Linde S.B. (1854), Stownik języka polskiego, t. I, wyd. 2, Lwów.

Lewaszkiewicz T. (2017), Język powojennych przesiedleńców z Nowogródka i okolicy, Poznań.

Mędelska J. (1993), Język polski na Litwie w dziewiątym dziesięcioleciu XX wieku, Bydgoszcz.

Mędelska J. (1999-2001), Język polskiej prasy wileńskiej (1945-1979), t. I-III, Bydgoszcz.

NSPP, Markowski A. (red.) (2000), Nowy słownik poprawnej polszczyzny, Warszawa.

Rudnicki S. (2000), Gwara polska wsi Korczunek koło Żytomierza, Warszawa.

SJPD, Doroszewski W. (red.) (1965), Stownik języka polskiego, t. II, Warszawa.

Stownik gwar polskich, oprac. i wyd. w IJP PAN w Krakowie, t. VI, z. 1 (16), Kraków 2001.

Smolińska B. (1983), Polszczyzna pótnocnokresowa z przełomu XVII i XVIII w.: na podstawie rękopisów Jana Władysława Poczobuta Odlanickiego i Antoniego Kazimierza Sapiehy, Wrocław.

SPPD, Doroszewski W., Kurkowska H. (red.) (1973), Stownik poprawnej polszczyzny, Warszawa.

SPPSzob, Szober S. (1968), Stownik poprawnej polszczyzny, wyd. 6, Warszawa.

SPXVI, Mayenowa M.R. (red.) (1971), Stownik polszczyzny XVI wieku, t. V, Wrocław.

Szpiczakowska M. (2001), Fonetyczne i fleksyjne cechy języka „Pana Tadeusza” Adama Mickiewicza na tle normy językowej XIX wieku, Kraków. 
Szwed J. (1931), Mów poprawnie! Stownik błędów językowych, Wilno.

Trypućko J. (1955-1957), Język Władysława Syrokomli (Ludwika Kondratowicza). Przyczynek do dziejów polskiego języka literackiego w wieku XIX, t. I-II, Uppsala.

Trypućko J. (1958), Źródła języka Mickiewicza, [w:] Adam Mickiewicz 1855-1955. Księga w stulecie zgonu, Londyn, s. 315-348.

Trypućko J. (1970), O języku Wspomnień dzieciństwa Franciszka Mickiewicza, Uppsala.

Turska H. (1939/1995), O powstaniu polskich obszarów językowych na Wileńszczyźnie, oprac. V. Čekmonas, Vilnius.

Turska H., (1930/1983), Język polski na Wileńszczyźnie [w:] Studia nad polszczyzna kresowa, t. II, pod red. J. Riegera i W. Werenicza, Wrocław 1983, s. 15-23 (przedruk z r. 1930).

Waszkis H. (1973), Język utworów J. U. Niemcewicza. Fonetyka i fleksja, „Rozprawy Komisji Językowej Wrocławskiego Towarzystwa Naukowego", t. 9, s. 171-215.

\section{Wykaz skrótów oznaczających informatorów}

Andr.LO[30] - kobieta, ur. w 1930 r. w Andrukańcach i tam mieszka, Wileńszczyzna.

Andr.LR[36] - kobieta, ur. w 1936 r. w Andrukańcach i tam mieszka, Wileńszczyzna.

Andr.PG[25] - kobieta, ur. w 1925 r., mieszka w Andrukańcach, Wileńszczyzna.

Aż.WM[27] - kobieta zam. w Ażełajciach k. Datnowa, ur. w 1927 r. w Wołujciach, pochodzi z rodziny chłopskiej, Kowieńszczyzna.

Bart.WP[31] - kobieta, ur. w 1931 r. w Boguszyszkach, pochodzi z rodziny szlacheckiej, mieszka w Bartuniszkach k. Kiejdan, Kowieńszczyzna.

Bej.IK[35] - kobieta, ur. w 1935 r. w pobliskich Lalupach, mieszka w Bejkielach, rejon ignaliński.

Bort.HC[35] - kobieta ur. w 1935 r. w Bortkiszkach i tam mieszka, rejon jezioroski.

Czer.HM[35] - kobieta, ur. w 1935 r., mieszka w Czeranach, rejon święciański, Wileńszczyzna.

Dat.RS[23] - mężczyzna, ur. w 1923 r. w pobliskim Podbrzeziu, pochodzi z rodziny szlacheckiej, mieszka w Datnowie, Kowieńszczyzna.

Duk.AS[46] - mężczyzna, ur. w 1946 r. w Dukiszkach i tam zamieszkały, rejon jezioroski.

Ejsz.IG[28] - kobieta, ur. w 1928 r. w Nowosadach, mieszka w Ejszyszkach, Wileńszczyzna.

Ejsz.JK[13] - kobieta, ur. w 1913 r. w Maciuńcach, mieszka w Ejszyszkach, Wileńszczyzna.

Ejsz.OS[27] - kobieta, ur. w 1927 r. w Ejszyszkach i tam mieszka, Wileńszczyzna.

Ejsz.TW[29] - kobieta, ur. w 1929 r. w Półstokach, mieszka w Ejszyszkach, Wileńszczyzna.

Gier.K[30] - kobieta, ur. w 1930 r., mieszka w Gierwiszkach, Wileńszczyzna.

Gir.AP[18] - kobieta, ur. w 1918 r., mieszka w Girsiach, rejon jezioroski.

Gow.JN[20] - kobieta, ur. w 1920 r. w Gowsztanach i tam mieszka, Wileńszczyzna.

Hąs.JK[34] - kobieta, ur. w 1934 r. w Hąskiewiczach, tam mieszka, Wileńszczyzna.

Imb.WP[39] - kobieta, ur. w 1939 r. w Niedożynkach k. Stalmujży, mieszka w Imbrodach, rejon jezioroski.

Jez.JW[36] - kobieta, ur. w 1936 r. w Dukiszkach, mieszka w Jeziorosach, rejon jezioroski.

Kab.MG[29] - kobieta, ur. w 1929 r. w Kabiszkach k. Niemenczyna i tam mieszka, Wileńszczyzna. 
Kaln.BS[24] - mężczyzna, ur. w 1924 r. w Kalniszkach i tam mieszka, rejon jezioroski.

Kam.ZK[33] - kobieta, ur. w 1933 r. w Kamionce k. Solecznik i tam mieszka, Wileńszczyzna.

Kiej.FT[13] - mężczyzna, ur. w 1913 r., mieszka w Kiejdanach, Kowieńszczyzna.

Kiej.RG[30] - kobieta, ur. w 1930 r., pochodzi ze szlachty, mieszka w Kiejdanach, Kowieńszczyzna.

Kiej.WK[36] - mężczyzna, ur. w 1936 r., mieszka w Kiejdanach, Kowieńszczyzna.

Kol.K[27] - kobieta, ur. w 1927 r. w Komorowszczyźnie (kolonia), mieszka w Koleśnikach w rejonie solecznickim, Wileńszczyzna.

Kom.BM[18] - mężczyzna, ur. w 1918 r. w Kompach k. Jaswojń i tam mieszka, pochodzi z drobnej szlachty, Kowieńszczyzna.

Kork.JK[11] - kobieta, ur. w 1911 r. w Wilnie, mieszka w Korkożyszkach, Wileńszczyzna

Kork.LM[38] - Wileńszczyzna.

Kork.SS[08] - kobieta, ur. w 1908 r. w Magunach, mieszka w Korkożyszkach, Wileńszczyzna.

Kork.WG[29] - Wileńszczyzna.

Korm.AG[15] - kobieta, ur. w 1915 r. w Kormiałowie, pochodzi z rodziny chłopskiej, Kowieńszczyzna.

Korm.WR[49] - mężczyzna, ur. w 1949 r. w Szyłanach, mieszka w Kormiałowie, Kowieńszczyzna.

Kow.JS[24] - kobieta, ur. w 1924 r. Lepszyszkach w rodzinie szacheckiej, mieszka w Kownie, Kowieńszczyzna.

Mag.BP[31] - kobieta, ur. w 1931 r., mieszka w Maguciach, rejon jezioroski.

Mag.MN[22] - kobieta, ur. w 1922 r. w Galiniszkach, mieszka w Maguciach, rejon jezioroski.

Magn.HS[44] - kobieta, ur. w 1944 r. w Słobodziszkach, mieszka w Magunach, Wileńszczyzna.

Magn.PJ[12] - kobieta, ur. w 1912 r. w zaścianku k. Magun (zlikwidowanym podczas melioracji), mieszka w Magunach, Wileńszczyzna.

Magn.WG[30] - kobieta, ur. w 1930 r. na kolonii k. Magun, mieszka w Magunach, Wileńszczyzna.

Magn.ZM[29] - kobieta, ur. w 1929 r. w Nasielanach, miesza w Magunach, Wileńszczyzna.

Mej.GJ[17] - kobieta, ur. w 1917 r. w Moskwie, mieszka od dzieciństwa w Mejsztach, rejon ignaliński.

Mej.TM[36] - kobieta, ur. w 1936 r., mieszka w Mejsztach, rejon ignaliński.

Mitr.HL[16] - kobieta, ur. w 1916 r. w pobliskich Erymajciach, pochodzi z rodziny szlacheckiej, mieszka w Mitrunach na Laudzie, Kowieńszczyzna.

Muk.JW[25] - kobieta, ur. w 1925 r. we wsi Łeki, mieszka w Mukulach, rejon jezioroski.

Nar.MS[20] - kobieta, ur. w 1920 r. w Ratuliszkach, mieszka w Narsuniszkach, rejon jezioroski.

Niem.CN[31] - mężczyzna, ur. w 1931 r. w Niemenczynie i tam mieszka, Wileńszczyzna.

Now.WK[26] - kobieta, ur. w 1926 r., mieszka w Nowikach, rejon jezioroski.

Ong.AU[13] - kobieta, ur. w 1913 r. w rodzinie polsko-litewskiej, mieszka w Ongirach, Kowieńszczyzna.

Ows.MB[24] - kobieta, ur. w 1924 r., mieszka w Owsłach, rejon jezioroski.

Pac.HS[25] - kobieta, ur. w 1925 r. w Paciunach i tam mieszka, rejon ignaliński.

Piad.J[12] - mężczyzna, ur. w 1912 r., mieszka w Piadziach, Kowieńszczyzna.

Piad.MJ[18] - kobieta, ur. w 1918 r. w Szatach, pochodzi z rodziny polsko-litewskiej, mieszka w Piadziach, Kowieńszczyzna. 
Podb.AP[15] - kobieta, ur. w 1915 r., mieszka w Podborzu, Wileńszczyzna.

Poj.TK[42] - kobieta, ur. w 1942 r. w Pojodubiu i tam mieszka, Wileńszczyzna.

Pren.HS[22] - kobieta, ur. w 1922 r. w Prenach i tam mieszka, Wileńszczyzna.

Rej.WM[22] - kobieta, ur. w 1922 r. w Bejkielach, mieszka w Rejbeniach, rejon ignaliński.

Rem.AC[29] - kobieta, ur. w 1929 r. w pobliskim Janowie, mieszka w Remejkach, rejon ignaliński.

Rom.RV[24] - mężczyzna, ur. w 1924 r. w Romańcach i tam mieszka, rejon jezioroski.

Rosz.SR[18] - mężczyzna, ur. w 1918 r. w Kiebowiczach, pochodzi z drobnej szlachty, mieszka w Roszczach k. Kiejdan, Kowieńszczyzna.

Smoł.AŻ[22] - kobieta, ur. w 1922 r., mieszka w Smołwach, rejon jeziorski.

Smołw.AS[39] - kobieta, ur. w 1939 r., mieszka w Smołweczkach, rejon jezioroski.

Stal.AP[35] - kobieta, ur. w 1935 r., mieszka w Stalmujży, rejon jezioroski.

Stal.JG[33] - kobieta, ur. w 1933 r. w Stalmujży i tam mieszka, rejon jezioroski.

Strył.JG[34] - mężczyzna, ur. w 1934 r. w Stryłungach i tam mieszka, rejon ignaliński.

Sz.BJ[17] - kobieta, ur. w 1917 r. w Narbuciszkach, pochodzi z drobnej szlachty, mieszka w Szatach, Kowieńszczyzna.

Szmel.PL[19] - kobieta, ur. w 1919 r. w Bieniaszach, mieszka w Szmelach, rejon ignaliński.

Szuk.HD[22] - kobieta, ur. w 1922 r. w Łekach, mieszka w Szukiszkach, rejon jezioroski.

Szuk.ZJ[23] - kobieta, ur. w 1923 r. w Szukiszkach i tam mieszka, rejon jezioroski.

Szuł.JS[33] - kobieta, ur. w 1933 r. w Zygmunciszkach, mieszka w Szułanach, rejon ignaliński.

Szuł.NK[30] - kobieta ur. w 1930 r., mieszka w Szułanach, rejon ignaliński.

Św.IP[27] - kobieta, ur. w 1927 r. w Świętobrości i tam mieszka, Kowieńszczyzna.

Św.OP[23] - mężczyzna, ur. w 1923 r. w Podbrzeziu, mieszka w Świętobrości, Kowieńszczyzna.

Trycz.LT[32] - kobieta, ur. w 1932 r., mieszka w Tryczunach, rejon ignaliński.

Tryk.WS[32] - kobieta, ur. w 1932 r., mieszka w Trykłaciszkach, rejon ignaliński.

Tryk.ZS[28] - mężczyzna, ur. w 1926 r w Trykłaciszkach i tam mieszka, mąż informatorki Tryk. WS[28], rejon ignaliński.

Und.HS[38] - kobieta, ur. w 1928 r., mieszka w Undrełanach, rejon ignaliński.

Urn.GA[1916] - kobieta, ur. w 1916 r. w Kulwie, pochodzi z rodziny szlacheckiej, od dzieciństwa mieszka w Urniażach k. Kiejdan, Kowieńszczyzna.

Weł.TS[35] - kobieta, ur. w 1935 roku koło Mejszt, mieszka w Wełunach, rejon ignaliński.

Wędz.AB[47] - mężczyzna, ur. w 1947 r. w Użumiszkach, mieszka w Wędziagole, Kowieńszczyzna.

Wędz.JB[46] - kobieta ur. w 1946 r., mieszka w Wędziagole, Kowieńszczyzna.

Wędz.JP[31] - kobieta, ur. w 1931 r. w Preszagole, pochodzi z drobnej szlachty, mieszka w Wędziagole, Kowieńszczyzna.

Wędz.SW[26] - mężczyzna, ur. w 1926 r. w Wędziagole i tam mieszka, Kowieńszczyzna.

Wędz.ZB[21] - kobieta, ur. w 1921 r. Mieszka w Wędziagole, Kowieńszczyzna.

Wil.JB[22] - kobieta ur. w 1922 r. , mieszka w Wilkach na Laudzie, Kowieńszczyzna.

WŁop.TK[32] - mężczyzna, ur. w 1932 r., pochodzi z drobnej szlachty, mieszka w Wielkich Łopiach, Kowieńszczyzna. 
Wod.LT[20] - mężczyzna, ur. w 1920 r. w Wodoktach na Laudzie i tam mieszka, Kowieńszczyzna. WSał.MK[14] - kobieta, ur. w 1914 r. w Załamance, mieszka w Wielkich Sałkach, Wileńszczyzna. Zyg.WT[34] - kobieta, ur. w 1934 r. w Zygmunciszkach i tam mieszka, rejon ignaliński.

Żeg.SW[20] - mężczyzna, ur. w 1920 r. w Żegowiczach k. Wędziagoły i tam mieszka, Kowieńszczyzna. 
